\title{
Enhancing Learners' Writing Performance through Blog-Assisted Language Learning
}

\author{
https://doi.org/10.3991/ijet.v14i09.9535 \\ Teguh Sulistyo ${ }^{(\varpi)}$ \\ Universitas Kanjuruhan Malang, Malang, Indonesia \\ Universitas Negeri Malang, Malang, Indonesia \\ sulistyoteguh@unikama.ac.id \\ Nur Mukminatien, Bambang Yudi Cahyono, Ali Saukah \\ Universitas Negeri Malang, Malang, Indonesia
}

\begin{abstract}
The present study aims at investigating how Blog-Assisted Language Learning (BALL) can enhance EFL tertiary learners' writing performance covering complexity, accuracy, and fluency through collaborative action research while at the same time it seeks to discover new knowledge that can inform the implementation of BALL in a writing class. This study employed Collaborative Classroom Action Research conducted in one cycle in one consecutive semester intended to make improvement in the teaching and learning of writing using BALL. There were 30 students of a university level majoring in English Education Department who joined Advanced Essay Writing Class in this study. The data were collected through interview, open-ended questionnaire followed by in-depth interview, and writing test. The findings showed that EFL learners improve their writing performance and they become more active in online class condition with two atmospheres: collaboration and competition among the learners.
\end{abstract}

Keywords-BALL; EFL Learners; writing performance; action research.

\section{Introduction}

Writing is a difficult activity for tertiary learners of English as a Foreign Language $(\mathrm{EFL})$. Many of them are frustated by the fact that they make a little progress in writing[1]. In this case, Gebhard [2] suggests that students need to pursue a process of creating and recreating when writing, so they discover and clarify within themselves what they want to express. Writing activities involve processing of multiple system [3] covering a series of interrelated steps in which attention given to one aspect of production may influence others [4].

Since writing is a demanding task [5] and the fact that writing concerns not only a product but also a process of discovery [6], teachers should be able to help students understand what they need to do in accomplishing a writing task. The reality, however, proves that most students do not cultivate self-reflective thinking on their own. 
Thus, they still need direct instruction and frequent reminders as well as a lot of training [7]. Purwanti [8] adds that in tertiary level of education, the new paradigm has changed from teacher-centered to learner-centered classroom. Accordingly, teachers are strongly advised to train students take more responsibilities for their own learning. In addition, dissatisfaction with controlled composition and the currenttraditional approach led to moving away from an emphasis on the written product to an emphasis on the process of writing [9]. In other words, the teaching of writing should motivate learners to be independent in writing activities because writing, as stated by Gebhard [2], not only deals with word choice, grammar, and organization but also focuses on the process of discovering meaning which needs some steps of writing.

In response to these phenomena, the process writing approach should not be conducted alone since it will probably be more effective if it is combined with the use of technology in teaching-learning process of writing since technology plays a significant role in teaching-learning process. Lavin, Korte, and Davies [10] mention that the trend toward the use of technology in the classrooms has escalated quickly as students have become increasingly tech-savvy. In addition, Fan [11] mentions that ICT is important to develop online foreign language teaching and learning. Domalewska [12] adds that technology assists students in the learning process modifying the way learning takes place, so learning is presented in technology-rich context. Amin [13] states that ICT in education comprises the acts of adopting elements of information and communication technologies in the teaching and learning process.

According to Lin, Groom, and Lin [14], advances in Information and Communication Technologies (ICT) are now widely considered as having advantageous roles for empowering the teaching and learning of second language writing. Boudjadar [15] mentions that there is a tendency to practice more writing on computers more than ever before; likewise, more people have adopted the habit of on-screen reading. Therefore, it stands to reason that ignoring the role of ICT in the writing classroom is irrational. In short, ICT should be integrated in teaching-learning process, including EFL writing class settings. Also, ICT is flexible in delivering education, that learners can gain access to knowledge anytime and anywhere [13].

One of the ICT modes which can be integrated with writing class settings is BlogAssisted Language Learning (BALL). It is an often-updated website that display entries containing texts, graphics, and topic-related hyperlinks usually in a reverse chronological order that can be commented by visitors [12]. Lin [16] explains that BALL covers any teaching-learning activities involving the use of blogs as a computer-mediated platform (1) where interactions both within and beyond the classroom take place between teachers and students and or among students, and (2) where language learning activities are observable.

The present study was also motivated by Lin [16] who suggests it be crucial to conduct further research on the impact of different forms of classroom organization on the students' overall writing performance using BALL. Then the major research questions are formulated as follows:

- How was BALL implemented to improve EFL learners' writing performance? 
- To what extent does Blog-Assisted Language Learning (BALL) improve EFL learners' overall writing performance?

\section{Review of Literature}

\subsection{The use of blog-assisted language learning in EFL writings}

In relation to process writing approach, Zhang [17] specifies BALL as a web-based space for writing where all the writing and editing of information is managed through a web browser and is immediately and publically available on the internet. In addition, Acar [18] avows that computer technologies including weblogs seem to be well integrated into writing classes, serving as an aid in creating an interactive atmosphere in which students can keep their motivation high, and by publishing the blog online students have the opportunity of writing for readers or classmates [17]. Boas [19] states that BALL offers learners opportunities to go through steps of writing consisting of pre-writing, drafting, peer review, and revising.

BALL, in relation to teaching-learning process of writing, is divided into three kinds: tutor blog, learner blog, and class blog ([12]; [14]; [17]). Tutor blog is created and organized by the teacher in order to provide course information, online materials, and reading practice. On the contrary, learner blog is initiated by the learner as a medium of writing and reading activities. Class blog is designed to provide course information such as materials, instruction of homework, and other class activities. In addition, class blog also facilitates students to communicate and share their essays with their classmates and teacher. The last kind of blog is used in the present study in integration with process writing approach.

BALL has some advantages in writing settings ([17]; [20]; [21]; [18]; [22]), such as promoting exploration of English websites, providing students' critical thinking skills, providing examples for students to model and to learn, affecting students' quality of writing, facilitating meaningful learning for students, and promoting teacher-student and student-student interaction inside and outside the classrooms. One such fact is that writing is really time consuming, so learners sometimes do not have enough time to accomplish their task of writing a single essay. Due to these reasons BALL is considered beneficial to improve learners' writing ability since it is flexible to be applied both inside and outside classrooms. Another consideration of the effect of BALL is that the posibility for learners to obtain more feedback since their draft is uploaded in the blog which enables their teacher and classmates to give them feedback.

\subsection{Major empirical potentials of BALL in writing classes}

Several studies addressing the use of blogs in writing has been conducted by researchers with different results. An ongoing research study examining the usefulness of a blog project in developing students' reading and writing skills conducted by Ho [23] found that "blogging can be a useful constructivist learning tool to supplement 
classroom teaching practice. If well integrated with face-to-face teaching, blogs can give students a very useful platform to practice their target language skills" and develop learner autonomy. Meanwhile, another study by Yunus et al. [21] proved that ESL learners can be motivated to improve their writing skills using blogs. However, Miyazoe and Anderson [24] who investigated learning outcomes and students' perception of online writing through blogs found that students have positive perception of blogs, but there are no significant learning outcomes. In addition, Kashani, Mahmud, and Kalahaji [25] also conducted research by comparing the effect of blogging and pen-and-paper based modes on Iranian graduate students' writing performance. The findings of the research revealed that blog does not affect the quality of the students' essays or their writing performance, yet it encourages them to write more enthusiastically in contrast with conventional methods, and they enjoy practicing it as an innovation in teaching and learning process.

Acar [18] investigating the use of internet in integration with process writing approach found that ESL writers could minimize their grammatical mistakes or unnatural expressions. In other words, the use of internet improves ESL writers' accuracy. Meanwhile, another study conducted by Fellner and Apple [26] revealed that the use of internet in teaching-learning process of writing is beneficial to improve students' writing proficiency in terms of fluency and lexical complexity. Camahalan and Ruley [27] also found that the use of internet in process writing approach has positive effect on most students' writing ability. Then more detailed findings of research conducted by Bawaneh [28] explains that there is a "positive association between the number of online files viewed by the students, the number of online discussion messages posted by the students, and their performance but no association between students' performance and the amount of time on the subject website". The results of the previous studies then prove the impact of BALL to facilitate learners' writing performance.

\section{Research Method}

This study employed Collaborative Classroom Action Research conducted in one cycle during one consecutive semester which was intended to make improvement in the teaching-learning of writing using BALL. To investigate how the strategy can improve EFL tertiary learners' writing performance, a frame of cycle of action research adapted from Lewin (1946 as cited in June [29]) consisting of 16 meetings (100 minutes per meeting) was adapted as the research procedures in the present study (see Figure 1). 

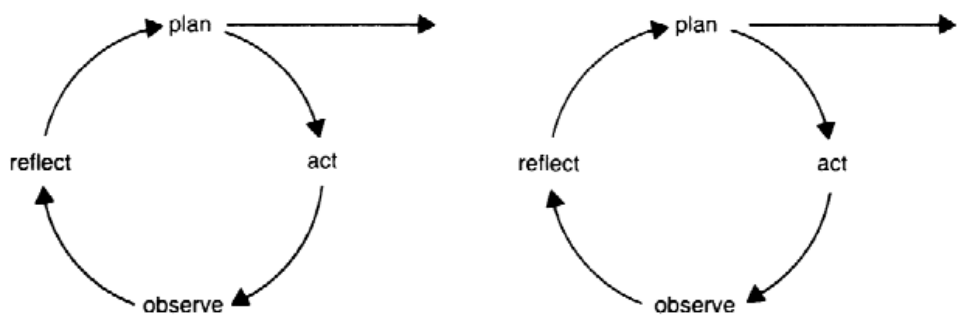

Fig. 1. Lewin's (1946 as cited in June, 2014) action research cycles

In this research, the researchers worked together with one of the writing class lecturers in conducting the action. Furthermore, one member conducted the action in cyclical process in one consecutive semester and the collaborative lecturer acted as an observer. The lecturer-researcher and the observer also scored the students' writing performance by using a scoring rubric in which the writing performance was based on three aspects, namely complexity, accuracy, and fluency.

The subjects of the research were 30 students in the Advanced-Academic Writing class of the Department of English in their fifth semester in a private university in Malang, Indonesia. They were taught to use BALL in the writing class. The instruments to collect data were field notes, open-ended questionnaire followed by indepth interview, and a writing test. In order to answer the research questions, some data were needed in dealing with learners' writing performance in terms of complexity, accuracy, and fluency.

To determine whether Blog-Assisted Language Learning (BALL) could improve EFL learners' writing performance in terms of complexity, accuracy, and fluency, the intervention was applied in a Collaborative Classroom Action Research in one semester consisting of 16 meetings. The first score taken in the second meeting was then compared with the final score to measure whether or not there was an improvement of the students' writing performance after they were treated using BALL in the Advanced Academic Writing Course. The scores were rated by two members: the first rater was one of the researchers and the second one was an English lecturer who also acted as a collaborator in this study. The involvement of two raters in scoring the students' writing performance aimed at providing greater reability as well as more objective measurement of the students' writing performance. Also, the scores given by the two raters were tested using Pearson Product Moment Correlation to measure the reliability of scoring the learners' writing performance.

Meanwhile, the intervension of Blog Assisted-Language Learning in the writing class was conducted through seven steps: setting up a class blog, providing text models, discussing a topic and activating students' background knowledge in prewriting activities, asking students to compose a text and post it in the blog, giving comments on students' drafts and asking the students give feedback on their classmates' drafts, asking students to revise their draft and post their final product, and asking students to read their classmates final products and give comments. 
The first step to accomplish was providing a class blog conducted by one of us as the lecturer. He, with the help of an ICT person, provided a class blog. BALL in integration with the process writing approach was implemented in the writing class, and a Wordpress blog was chosen for the present study since Wordpress blogging provided two main advantages. First, it was not cluttered with advertisements which possibly distracted students' focus in doing writing activities or reading the contents of the blog. Second, it was very easy for the students to set up an-email account and simple password as well as a user name combination to log on the blog. Thus, it was only the members of the blog who posted their products - in the forms of drafts and final products - and commented on any product.

Second, some text models were provided in order to help the students understand the standard, targeted linguistic forms, and stuctures they had to achieve in the writing class. By providing some text models, we hoped that the students understood the standard of texts they had to compose in the course. In addition, the text models might help the students analyze parts of an essay easily and the models probably provided a guidance how to write an essay.

The next step was discussing a new topic and cultivating students' background knowledge in pre-writing activities. Empowered with wifi, the students were asked to search and read some texts or articles dealing with the topic. Then they discussed the topic in a small group in order to enrich their schemata, and then they made an outline.

The fourth step was asking students to write a rought draft. The students wrote their draft in the classroom and outside the classroom. In this step the students did not have enough time to finish their rought draft, so they continued writing their draft outside the classroom. Finishing their draft, they posted it in the blog.

The following step provided feedback on the students' drafts. The lecturer gave feedback on each student's draft, and he asked the students to give comments or feedback on their classmates' drafts in the blog. This was performed in the classroom and outside the classroom.

The sixth step was that the students were guided to revise their draft after getting teacher and classmate feedback. In this phase, the students revised their draft based on the feedback they had got. In addition, the teacher encouraged the students to discuss the feedback they had got if they did not understand the feedback. The purpose of the revising activities was to improve the quality of the students' drafts before they posted their final essays in the blog.

Finally, after the students posted their final essays, the teacher instructed them to read their classmates essays. By doing so, it was hoped that they could share their final essays with their classmates. They were also encouraged to give comments on the essays they had read. In this step, the teacher also gave his overall comments on the activities of the writing class using BALL and the essays which the students composed. 


\section{$4 \quad$ Results and Discussion}

Figure 2 shows the development of EFL learners' writing performance development. The level of significance was reliable at .696. Thus, the two scores taken from Rater 1 and Rater 2 fulfilled the need of the inter-rater reliability. In addition, as Figure 2 indicates, the students made a low improvement after being treated using BALL. Complexity of the students' writing performance increased from 21.60 to 23.23 (the scores range $0-30$ ) and it was equivalent to $7.55 \%$. Meanwhile, accuracy developed from 13.57 to 14.53 (the scores range $0-20$ ) or $7.07 \%$; fluency improved from 40.47 to 43.58 (the scores range $0-50$ ) or $7.68 \%$, and as a whole their average scores raised from 75.63 to 81.35 (the scores range $0-100$ ) or $7.56 \%$. It was also found that there were 6 students who got scores under 80 as the minimum target to be achieved.

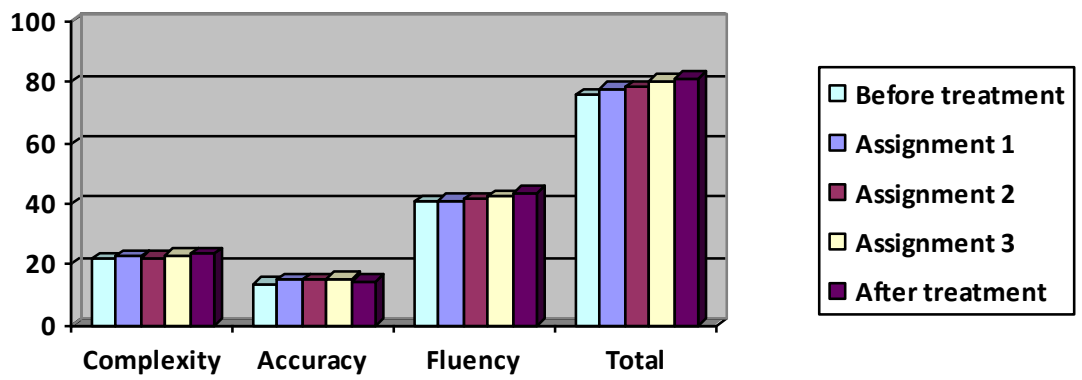

Fig. 2. EFL learners' writing performance development

The students' writing scores taken before and after the treatment of BALL were then compared. The results showed that the students' average writing scores improved from 75.63 to 81.35 , indicating that at the end of the term the students made progress in their overal writing performance. In addition, the analyticallly-inter rated scores proved that the students' mean scores increased in terms of complexity, accuracy, and fluency. Writing performance are commonly measured based on three aspects: complexity, accuracy, and fluency (CAF) in the target language ([30]; [31]). In the present study CAF are measured by combining each aspect with an analytical scoring rubric adapted from Skehan [32] and Bacha (2001) cited in Klimova [33].

The results of the present study suggest some insights dealing with the benefits of Blog Assisted-Language Learning in writing activities. Several previous studies proved that BALL was beneficial to improve students' writing peformance. For instance, Acar [18] found that BALL, if it is well integrated into writing classes, serves as a tool in creating an interactive condition, and it enables the students to increase their grammatical accuracy and be aware of unnatural expressions, so they can create more natural expressions or sentences. In addition, BALL has some benefits ([17]; [30]; [21]), such as providing students' critical thinking skills, 
providing texts models to learn and imitate, affecting students' quality of writing, faciliting teacher-student and student-student interaction within and beyond the classrooms. Meanwhile, Lin et al. [14] revealed that ICT, including BALL, has important potentials for enhancing the teaching-learning process of second language writing activities.

In line with the findings above, Lin [16] also found that the implementation of BALL cultivates learner-centered learning and helps students increase their writing skills, motivation, and self-efficacy. Somehow, Lin also revealed that the students are worried about producing linguistically wrong sentences since they know that they have an online audience. Squires [34] added that the students tend to spend longer time choosing linguistic forms and checking their errors before publishing it for the online audience. Then Muliani [35] conducted a study on BALL and the findings showed that the students and the teachers do not worry about loosing the writing papers as the students' products are stored online, and students have real audiences for their publication. A possible reason is that most writing in general has an audience limited to one or two teachers only, but the blog allows them to have more audiences, so they work much harder on their publications in the blog so as to be understood by the online audience.

In addition, $\mathrm{Li}$, Bado, and Moore [36] found that interactive blogging affects learners' reflective and critical thinking in writing. Thus it stands to reason to avow that students' writing performance increased because they have reflective and critical thinking, and they become more independent because of learner-centered learning in which the students are more active. Zhang, Shong, Shen, and Huang [37] also conducted a study using a mix method involving 36 students majoring in English to examine the effects of blog on students' writing abilities and they found that the students improved their writing abilities and reduced their independency to their teacher. Thus, they possesed the potentials to enrich self-regulation and autonomous learning in the target language among the students. In fact, in accomplishing their tasks in writing, students need to monitor their own work dealing with the cultivation of a sense of responsibility for being critical to the writing [38]. It shows that writing quality is also affected by students's attitudes in doing their writing activities. It is also supported by the findings of the research by Boudjadar [15] which revealed that blogs have potentials to encourage discussion and provide feedback, so the students are motivated to do harder efforts to improve their writing qualities.

In contrast, Miyazoe and Anderson [24] examining the effects of blog in the writing class revealed that there were no significant contribution of blog in improvinng students' writing ability, yet they had positive perceptions towards the use of blog. Also, Kashani, Mahmud, and Kalajahi [25] who conducted research by comparing the effects of blogging and pen-and-paper based modes in the writing class did not find any significant effect on the students' writing quality. Rifai [39] also found that students' lack of enthusiasm was correlated to students' level of achievement in writing, and blog did not give significantly effect on students' writing performance.

A study by Ahluwalia, Gupta, and Anggarwal [40] provided more comprehensible phenomena as indicated by the students' better writing performance since BALL is 
easy to manage and empowers students to publish their work in a cronological manner. BALL also helps students to take part in online exchanges and promote their autonomous learning. Their willingnes to join the blog in integration with autonomous learning seems a great factor that drives students to work hard resulting on better students' writing performance. According to Zhang [17], " blogs offer five main roles for L2 English students:

- Helping students to maximize their critical thinking skills

- Providing examples for students to model and learn from

- Affecting students' writing performance

- Providing meaningful learning activities for students

- Motivating students a purpose of writing."

By participating in online discussion in the blog, the students maximized their critical thinking because they had to do self-evaluation on their own products and those of their peers [41]. In addition, the products posted in the blog acted as models affecting students' writing quality. Another role of blogs is faciliting meaningful learning for the students, so they are motivated to write since they have a purpose why they have to write a text. Barrios [42] suggests that students basically have no intension to write unless they have to do and blogs can be a means to change that, so teachers need to cultivate the writing habit. If they are engaged with technology, a blog can be an appropriate tool to achieve beneficial outcomes in this project.

Answering the second question which says "How was BALL implemented to improve EFL learners' writing performance?", it was found that the ideal of BlogAssisted Language Learning in integration with process writing approach could be employed over seven stages done within and beyond the classroom. BALL in this study was integrated with process writing approach since according to Cahyono [38], this approach focuses on what goes on when students accomplish their writing task and what teachers can do to facilitate the students get into the natural steps of writing, and the fact that writing is a demanding task [5]. In addition, Randacio [9] believes that the teaching-learning processes of writing move away from product orientation to process of writing-based activities. Thus, the intervention of BALL was implemented in integration with steps of writing, namely pre-writing, drafting, revising, writing final product, and publishing it in the blog. BALL in integration with process writing approach were applied in seven steps:

1. Setting up a class blog

2. Providing text models

3. Discussing a topic and activating students' background knowledge in pre-writing activities

4. Asking students to compose a text and post it in the blog

5. Giving comments on students' drafts and asking the students give feedback on their classmates' drafts

6. Asking students to revise their draft and post their final product

7. Aasking students to read their classmates final products and give comments. 
Boudjadar [15] claims that blogs have potentials to lead discussion and provide feedback, so students are motivated to pursue harder efforts to improve the quality of their writing products. Also, Abidin, Mohammadi, and Hamid [43] discovered that students are encouraged to collaborate more through sharing ideas indicating noticable readiness, eagerness, and satisfaction. Aydin [44] also found that blogs are effective to cultivate participation in peer feedback activities. Thus, technology is beneficial in teaching-learning process of writing, and BALL allows the students to have the benefits inside and outside the classroom.

\section{Conclusion}

The findings show that students improved their writing performance in terms of complexity, accuracy, and fluency after being treated using BALL in integration with process writing approach. BALL provides flexible writing activities since it allows students to accomplish their tasks within and beyond the classroom. After the students were trained to use BALL, they got more active and independent so that the class becomes more focused on student-centered learning. This condition motivates them to work harder in accomplishing their tasks. They have chances to collaborate with their classmates by sharing and giving comments in the blog, but at the same time they try to compete to be better in producing their essays.

In addition, knowing that they have real audiences, in this case online audiences, for their writing publication, they tend to work harder and more carefully before publishing their essays. A possible reason is that most writing in general has an audience limited to one or two teachers only, but the blog allows them to have more audiences: their lecturer and classmates, so they work much harder on their publications in the blog so as to be understood by the online audiences. In short, after the students were trained to use BALL, they improved their writing performance in terms of complexity, accuracy, and fluency. It stands to reason to avow that BALL with its flexibility in which they can do steps of writing inside and outside the classroom motivates students to work in two sides: collaboration and competition. This atmosphere motivates students to do their best, and finally they can improve their writing performance.

\section{References}

[1] Xiao, Y.H. (2008). Applying metacognition in EFL writing instruction in china. Reflections on English Language Teaching, 6(1):19-33.

[2] Gebhard, J.G. (2000). Teaching English as a foreign or second language. a teacher selfdevelopment and methodology guide. Ann Arbor. The University of Michigan Press.

[3] Abedifirouzjaie, J. (2014). The effect of different strategic planning foci on accuracy of writing task performance. Texas Papers in Foreign Language Education, 16 (1): 43-58.

[4] Seyyedi,K., Ismail, S.M.M.M., Orang, M., \& Nejad M.S. (2013). The effect of pre-task and online planning conditions on complexity, accuracy, and fluency on EFL learners ' 
Paper-Enhancing Learners' Writing Performance through Blog-Assisted Language Learning

written production. English Language Teaching, 6(12):1-10. https://doi.org/10.5539/elt.v6n12p1

[5] Ruan, Z. (2005). A metacognitive perspective on the growth of self-regulated EFL student writers. Reading Working Papers in Linguistics, 8:175-202.

[6] Sulistyo, T. \& Heriyawati, D.F. (2017). Reformulation, text modeling, and the development of EFL academic writing. Journal of English as a Foreign Language, 7 (1): 1-15. https://doi.org/10.23971/jefl.v7i1.457

[7] Joseph, N. 2006. Strategies for Success: Teaching Metacognitive Skills to Adolescent Learners. The Nera Journal, 42 (1): 33-39.

[8] Purwanti, T.T. (2015). The implementation of self-assessment in writing class: a case study at STBA LIA Jakarta. TEFLIN, 26(1): 97-116. https://doi.org/10.1 5639/teflinjournal.v26i1/97-116

[9] Randaccio, M. (2013). Writing skills: theory and practice. QuaderniCIRD, 7: 51-74, 7vin, A.M., Korte, L., \& Davies, T.L. (2012). The impact of classroom technology on student behaviour. Journal of Technology Research, 1-13.

[10] Lavin, A.M., Korte, L., \& Davies, T.L. (2012). The impact of classroom technology on student behaviour. Journal of Technology Research, 1-13.

[11] Fan, J.H. (2018). On Computer and Foreign Language Teaching and Learning in Big Data Era. iJET, 13 (5): 236-245. https://doi.org/10.3991/ijet.v13i05.7717

[12] Domalewska, D. (2014). Technology-supported classroom for collaborative learning: blogging in the foreign language classroom. International Journal of Education and Development using Information and Communication Technology (IJEDICT), 10 (4): 21-30.

[13] Amin, S.N. 2013. An Effective Use of ICT for education and Learning by Drawing on Worldwide Knowledge, Research, and Experience: ICT as a Change Agent for Education. http://www.nyu.edu/classes/keefer/waoe/ amins.pdf. Retrieved January 10, 2016.

[14] Lin, M.H., Groom, N., \& Lin, C.Y. (2013). Blog-assisted language learning in the ESL writing classroom: a phenomenological analysis. Educational Technology \& Society, 16 (3): 130-139.

[15] Boudjadar, T. (2015). ICT in the writing classroom: the pros and the cons. International Journal of Applied Linguistics \& English Literature. Vol. 4 (1): 8-13. https://doi.org/10.75 75/aiac.ijalel.v.4n.1p.8

[16] Lin, M.H. 2015. Learner-centered blogging: A preliminary investigation of EFL student writers' experience. Educational Technology \& Society, 18 (4): 446-458.

[17] Zhang, D. (2009). The application of blog in English writing. Journal of Cambridge Studies, 4 (1): 64-71.

[18] Acar, A., Geluso, J., \& Shiki, T. (2012). How can search engines improve your writing. CALL-EJ, 12 (1):1-10.

[19] Boas, I.V. (2011). Process writing and the internet: blogs and ning networks in the classroom. English Teaching Forum, 2: 26-33.

[20] Wu, W.S. (2014). Using blogs in an EFL writing class. http://citeseerx.ist.psu.edu/viewdoc/download?doi=10.1.1.476.3456\&rep=rep1\&type=pdf. Retrieved January 10, 2016.

[21] Yunus, M.M., Tuan, J.L.K., \& Salehi, H. (2012). Using blogs to promote writing skill in ESL classroom. Recent Advances in Educational Technologies. http://www.wseas.us/e-library/conferences/2012/Vienna/COMPUTERS/ COMPUTERS58.pdf. Retrieved January 13, 2016.

[22] Wanajak, K. (2011). Internet use and its impact on secondary school students in Chiang Mai, Thailand. Edith Cowan University. Unpublished Dissertation. 
[23] Ho, G.A.L. (2009). Blogging and Vietnamese language teaching and learning. Electronic Journal of Foreign Language Teaching, 6:268-277.

[24] Miyazoe, T. \& Anderson, T. (2010). Learning outcomes and students' perceptions of online writing: simultaneous implementation of a forum, blog, and wiki in an EFL blended learning setting. System, 38 (2):185-199. https://doi.org/10.1016/j.system.2010.03.006

[25] Kashani, H., Mahmud, R.S., Kalajahi, S.A.R. (2013). Comparing the effect of blogging as well as pen-and-paper on the essay writing performance of iranian graduate students. English Language Teaching, 6 (1): 202-218. https://doi.org/10.5539/elt.v6n10p202

[26] Fellner, T. \& Apple, M. (2006). Developing writing fluency and lexical complexity with blogs. The JALT Call, 2:15-26.

[27] Camahalan, F.M.G. \& Ruley, A.G. (2014). Blended learning and teaching writing: a teacher action research project. Journal of Instructional Pedagogies, 14: 1-13.

[28] Bawaneh, S.S. (2011). The effects of blended learning approach on students' performance: evidence from a computerized accounting course. International Journal of Humanities and Social Science, 1 (6): 63-69.

[29] June, S., Yaacob, A., and Kheng, Y.K. 2014. Assessing the Use of YouTube Videos and Interactive Activities as a Critical Thinking Stimulator for Tertiary Students: An Action Research. International Education Studies, 7 (8): 56-67. https://doi.org/10 $.5539 /$ ies.v7n8p56

[30] Tavakoli, M. \& Rezazadeli, M. (2014). Individual and collaborative planning conditions. effect on fluency, complexity, and accuracy in L2 argumentative writing. The Journal of Teaching Language Skills (JTLS), 5 (4): 85 - 110.

[31] Pourdana, N \& Behbahani, M.K. (2011). Task types in efl context: accuracy, fluency, and complexity in assessing writing performance https://www.google.co.id/url?sa=t\&source=web\&rct=j\&url=http://www.ijssh.org/papers/7 3-088.pdf\&ved=2ahUKEwjjn96lpdXZAh UBupQKHZG9DAMQF jAAegQIBxAB\&usg =AOvVaw2stov MFi_XR4dy9YV1YqRd. Accessed on April 2017.

[32] Skehan, P. (2009). Modelling second language performance: integrating complexity, accuracy, fluency, and lexis. Applied Linguistics, 30(4): 510-532. https://doi.org/10. 1093/applin/amp047

[33] Klimova, B.F. (2011). Evaluating writing in English as a second language. Social and Behavioral Sciences, 28: 390-394. https://doi.org/10.1016/j.sbspro.2011.11.074

[34] Squires, S.B. (2010). An investigation into the use of blog as a tool to improve writing in the second language classroom. An Unpublished Dissertation. Manchester: The University of Manchester.

[35] Muliani, D.N. (2010). The internet as an aid in developing writing skills. Educationist, 4 (1).

[36] Li, K., Bado, N., Smith, J., \& Moore, D. (2013). Blogging for teaching and learning: an examination of experience, attitudes, and levels of thinking. Contemporary Educational Technology, 4 (3): 172-186.

[37] Zhang, H., Song, W., Shen, S, and Huang, R. (2014).The effects of blog-mediated peer feedback on learners' motivation, collaboration, and course satisfaction in a second language writing course. Australasian Journal of Educational Technology, 30(6): 670-685. https://doi.org/10.14742/ajet.860

[38] Cahyono, B.Y. (1999). Converging lines: towards the integration of second language research and teaching. K@ta, 1(1): 32-43. https://doi.org/10.9744/kata.1.1.32-43

[39] Rifai, I. (2010). Students' attitudes on the use of facebook and blog in writing class and their writing competence. Jurnal Lingua Cultura, 4 (10): 25-38. https://doi.org/10.2 $\underline{1512 / \text { lc.v4i1.348 }}$ 
[40] Ahluwalia, G., Gupta, D.A., \& Aggarwal, D. (2011). The use of blogs in english language learning: a study of student perceptions. Profile, 13 (2): 29-41.

[41] Dizon, G. (2016). Enhancing english learners' writing fluency and lexical richness through timed blogging. The Language Teacher, 40 (1): 9-13.

[42] Barrios, B. (2010). Blogs as writing practice. Retrieved from: http://www.bgsu.edu/cconline/barrios/blogs/write/index.html.

[43] Abidin, M.J.Z., Mohammadi, M.P., \& Hamid, F.B.A. (2011). Blogging: Promoting Peer Collaboration in Writing. International Journal of Business, Humanities, and Technology, 1 (3): $98-105$

[44] Aydin, S. (2014). The use of blogs in learning English as a foreign language. Mevlana International Journal of Education, 4 (1): 244-259. https://doi.org/10.13054/mije.13.79.4.1

\section{$7 \quad$ Authors}

Teguh Sulistyo is a doctorate student of Graduate Program in English Language Teaching of Universitas Negeri Malang. He also teaches English at Universitas Kanjuruhan Malang, Indonesia.

Nur Mukminatien, Bambang Yudi Cahyono, and Ali Saukah teach English at the English Department and Graduate Program in English Language Teaching of Universitas Negeri Malang, Indonesia.

Article submitted 2018-09-12. Resubmitted 2019-02-26. Final acceptance 2019-03-23. Final version published as submitted by the authors. 